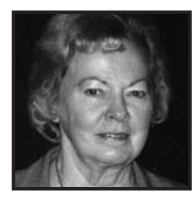

\title{
Commentary: Responsibility
}

\author{
Nel Noddings, Professor Emerita, Stanford University
}

\section{ABSTRACT (Press Here for Sound)}

In this commentary, I argue that the current emphasis on accountability has overshadowed and weakened the far deeper concept of responsibility, and I ask readers to reflect on the scope and significance of teachers' responsibilities. Accountability, defined too narrowly, demeans the work of teachers and may even invite corruption. In contrast, a serious look at responsibility leaves us in some awe at the breadth and importance of the work we undertake as teachers.

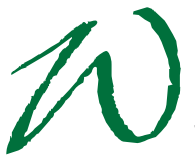

e live in an age of accountability, and the demand for accountability seems to have diminished the role of responsibility. I will argue here that this is a bad mistake. Accountability forces us to answer to authorities for what we have accomplished or failed to accomplish; it points upward in the chain of power, and it encourages compliance or the appearance of compliance. We have to satisfy some authority that we have met some specific goal. There is some evidence that emphasis on accountability may even invite corruption. People, so focused on showing that they have met a particular goal, may cheat or "fudge" a bit to avoid penalties and criticism. In contrast, responsibility points downward in the power chain; it asks us to respond to the legitimate needs of those placed in our care. It is not satisfied by meeting one narrow goal.

Consider the breadth of responsibility in teaching. Teachers are responsible to various degrees for the physical and psychological safety of their students. Teachers of very young children must be constantly aware of physical dangerstripping over carelessly placed belongings, swallowing dangerous objects. Teachers in secondary schools and colleges do not worry much about dangers of this sort, but 
they must protect their students from embarrassment and verbal harassment. Teachers who use sarcasm or indulge in scornful responses to students' comments are derelict in this duty; their behavior is irresponsible.

Even when students are safe from ill treatment at the hands of their teachers, however, they may experience harassment by their peers. At every level, responsible teachers must protect their students against verbal bullying by other students. Here, teachers have several related responsibilities: First, they must eliminate such behavior as nearly as possible; they must protect the victim. Second, they must do what they can to correct and support the perpetrator; bullies must be helped to understand their behavior and work to change it. Third, they must encourage their students to share responsibility for a safe, cooperative classroom climate. Accepting this responsibility, good teachers do not rely heavily on authoritarian control but, rather, on a form of consistent guidance. They talk with their students about social problems, manners, and the rewards of dialogue. A healthy, safe classroom depends on mutual trust and respect.

Teachers have some responsibility for both emotional safety and intellectual honesty. Every conscientious teacher knows how difficult it can be to manage these two great responsibilities. Some teachers, wanting to protect their students from the embarrassment of public correction, react to every student contribution with, "good," even though a response may be plainly wrong. It takes skill and sensitivity to the needs of an individual student to provide correction without discouraging or humiliating him/her. Suppose a student expresses enthusiasm for the expression "government of the people, by the people, and for the people" but wrongly attributes it to the U.S. Declaration of Independence. The teacher can sustain the student's enthusiasm and encourage further exploration, but she must also remind the class that the words are from Lincoln's Gettysburg Address. Similarly, when a student gives a wrong answer to a mathematics problem, the teacher may say, "Let's see how you got that," and then suggest that three or four students simultaneously show their work on the chalk (or white) board. The ensuing discussion can invite something very like detective work on the part of a class seeking not only the right answer but further knowledge about procedures and pitfalls. Working together in this fashion, teachers can show that students who get wrong answers can still contribute to the search for knowledge.

Part of a teacher's job is to help students take greater responsibility for their own learning. This is not simply a matter of turning work in on time and passing tests, although there is a temptation for teachers under the pressure of accountability to 
put the same pressure on students. In many classes, students are told exactly how many points they will be awarded for every task assigned. They are also told exactly how many points will be deducted for late work. It is not surprising that many students lose their love of learning and concentrate exclusively on points and grades.

Everyone recognizes that teachers have some responsibility for the intellectual development of their students, but too often today that responsibility is downgraded to a demand for higher test scores, and teachers are expected to "deliver" instruction on a tightly prescribed curriculum. In the best schools, however, teachers share responsibility for selecting curriculum topics and materials. They do not simply teach item by item, word for word exactly what authorities have defined as the curriculum. David Hawkins, the philosopher of science who contributed so much to open education, described the attitude toward curriculum in Dewey schools. Answering the criticism that such schools had no curriculum, he noted that in fact they

had a definite curriculum and there was no freedom to depart from this curriculum ... Within this, [however] teachers were enormously free to pursue these general subject-matter situations in any way they wanted to and it was quite clear also ... that an important group involved in making those decisions was the children themselves. (Hawkins, 1973, p. 498)

The freedom to choose within obvious limits-mathematics teachers must teach algebra if that is their assignment-places heavy professional responsibility on teachers. Working with the interests of students, teachers provide different educational projects and assignments for various groups and individuals. This responsibility is both demanding and delightful. It requires listening to students and responding to changes in the classroom environment. It also requires continued study and the exercise of imagination by teachers.

Not long ago, I chatted with an elementary school teacher, Mrs. X, who told me why she had taken early retirement. She had apparently been highly successful, and she loved her work, but the atmosphere had changed in recent years. One day, her fourth graders became very excited by the season's first snowfall. Instead of insisting that they stop looking out the windows and attend to the planned lesson, she invited them to write poems about snow and winter activities. The kids were enthusiastic. Some illustrated their poems. Some softly sang songs about sleigh bells and sleds. They talked about rhythm and rhyme. In the middle of this activity, a supervisor came in and sat down for an observation. Later the supervisor reprimanded the teacher for being "off the curriculum." This activity was not in the official lesson plan. 
The teacher protested that she had taken advantage of a "teachable moment." The supervisor replied scornfully that there is no such thing as a teachable moment. For Mrs. X, this response suggested that her years of creative lessons and enthusiastic cooperation with children now meant nothing. She was expected to do exactly what her approved lessons plans stated, and to receive that approval, she had to state a specific learning objective for every lesson. Accountability interpreted so narrowly may drive many creative, highly effective teachers out of the public schools.

Teachers clearly have a responsibility to teach the standard subject matter prescribed in the pre-active curriculum-provided that material is not too narrowly defined-but they also have a responsibility to teach other important things. Recently, I attended the funeral of an old friend, Wil, who had been an industrial arts teacher. One of the speakers was a former student of Wil's. In his remarks, he said that his former teacher-obviously much loved_-had taught him to speak grammatically and to exercise leadership responsibly (he was president of his senior class). Think about this. The boy learned from his industrial arts teacher, not his English teachers, to speak grammatically. My old friend had taken seriously a responsibility to teach the "whole child." The speaker also told us that Wil had advised him to work cooperatively, recognize the work of others, and interact more diplomatically. As a result, a somewhat rebellious and self-centered boy became a successful class president.

Teachers are responsible for so much more than the specific subject matter of their own courses. In addition to preparing students for the next grade or course, they must be concerned with permanent or long-lasting learning. Over the years, students forget much of what they are taught in school. Indeed, all of us forget a mass of details we once learned in order to pass classroom tests. But responsible teachers hope that students will retain certain habits of mind, intellectual curiosity, and eagerness (or at least willingness) to go on learning. When a teacher sees that a set of lessons is killing the joy of learning, she reasonably creates new, worthwhile activities that may restore the desire to learn.

In responding to necessary changes and teachable moments, teachers design activities that further the development of thinking, organizing, and communicating. A good teacher does not simply give up and let kids do whatever they please when they show signs of being bored and restless. Keeping their interests in mind, she suggests activities that are likely to further the great aims of education. When the fourth graders in Mrs. X's class wrote poems about the new snow, they were sharing ideas, writing, communicating, reading each other's work, conferring about spelling and, yes, dreaming a little about sleds and snowballs. 
We sometimes forget, in today's climate of accountability, that teachers are responsible not only for specific outcomes but also for what is offered. Responsible teachers are always learning, collecting anecdotes and objects, preparing for possible lessons that may seem spontaneous to observers. They offer topics, stories, and challenges that may excite the interest of some students, but they do not insist that every student must pursue a given offering. They invite new ideas from students, and they watch to see whether students become absorbed and work toward satisfactory completion or whether they flit restlessly from one topic to another. In the latter case, teachers accept some responsibility for helping youngsters to study their own habits, to settle down, to see things to completion.

In addition to a wide array of intellectual habits, teachers are also responsible for the development of social and ethical attitudes and dispositions. In the United States today, we are beginning to realize that bright, ostensibly well-educated people are too often greedy, insensitive, and even dishonest in their personal and occupational roles. We do not, and should not, blame elementary or secondary teachers for the social/moral deficiencies widely observed. But teachers do bear some responsibility for moral education. The question is how to go about this essential task. Should we establish courses specifically designed to teach morals? Should we publicize a set of explicit rules, together with equally explicit penalties for their infraction? Should we institute zero-tolerance rules? Should we tighten control, perhaps hire more police for our schools?

There is much debate on these questions, and the debate reminds us of another teacher responsibility. Teachers should know what is going on in their field. They should read, continue to learn, and be able to justify the answers they give to educational questions. For those of us who take a neo-progressive position on the whole child and related matters, every teacher is a moral educator and, to some degree, responsible for the continuing moral growth of her students. Even at the graduate level, many of us feel a responsibility to engage our students in a discussion of honor codes, plagiarism, intellectual honesty, and professional ethics. As we accept this responsibility, we recognize another-to listen to alternative views and commit ourselves to dialogue.

Consider the role of teachers in preparing students for life in a democratic society. Should responsibility fall entirely on social studies teachers? They are the ones who teach the history of their nation and introduce students to governmental documents and procedures. But is that enough? Again, many of us believe that every teacher has some responsibility to involve students in democratic processes and to 
teach some of the skills required. Such teachers may establish class meetings at which students discuss the rules by which they will govern themselves. They encourage students to work together and use group work not only to enhance learning but also to increase the communicative skills needed in democratic life. They support a rich agenda of extracurricular activities because these activities provide a venue for students with very different academic interests to work together-electing leaders, planning and implementing activities, perhaps volunteering to work with community organizations.

Clearly, we could continue in this vein for volumes. Do teachers have some responsibility for their own intellectual growth? For the aesthetic development of their students? For spiritual development? For satisfying personal and family life? Notice that responsibility is broader and deeper than accountability. It is not so much concerned with answering to external authorities. It is reflective and answers to something essential inside us.

In emphasizing responsibility, I do not mean to suggest that teachers should reject accountability entirely. Of course, we are properly accountable to those who hire us and to our professions. If we have charge of monies and materials, we should expect to account for how we use them. But accountability is far too weak a concept by which to judge the work of teachers, and when it is used too narrowly, it actually demeans our work and undermines the effort to increase the quality of teaching. Taking responsibility seriously leaves us in some awe at the scope and significance of the work we have undertaken.

\section{References}

Hawkins, D. (1973). How to plan for spontaneity.

In C.E. Silberman (Ed.), The open classroom

reader (486-503). New York: Vintage

Books. 


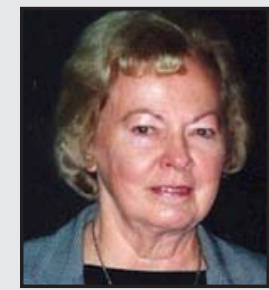

Nel Noddings is Lee L. Jacks Professor of Education, Emerita, at Stanford University. She is a past president of the National Academy of Education, the Philosophy of Education Society and the John Dewey Society. In addition to 16 books, she is the author of more than 200 articles and chapters on various topics ranging from the ethics of care to mathematical problem solving. Her latest books are Happiness and Education, Educating Citizens for Global Awareness, Critical Lessons: What Our Schools Should Teach, and most recently When School Reform Goes Wrong.

Noddings spent 15 years as a teacher, administrator, and curriculum supervisor in public schools; she served as a mathematics department chairperson in New Jersey and as Director of the Laboratory Schools at the University of Chicago. At Stanford, she received the Award for Teaching Excellence three times. She also served as Associate Dean and as Acting Dean at Stanford for four years. 